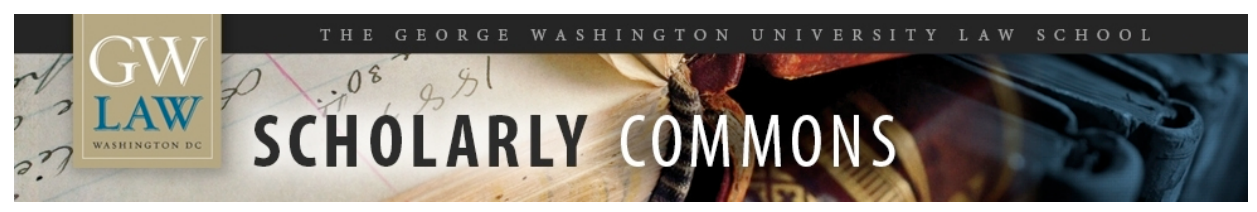

\title{
Judicial Innovations to Screen Eyewitness Identifications
}

Stephen A. Saltzburg

George Washington University Law School, ssaltz@law.gwu.edu

Follow this and additional works at: https://scholarship.law.gwu.edu/faculty_publications

Part of the Law Commons

\section{Recommended Citation}

Saltzburg, Stephen A., Judicial Innovations to Screen Eyewitness Identifications (2013). 28 Crim. Just. (2013);; GWU Law School Public Law Research Paper No. 2015-31; GWU Legal Studies Research Paper No. 2015-31. http://ssrn.com/abstract=2642267

This Article is brought to you for free and open access by the Faculty Scholarship at Scholarly Commons. It has been accepted for inclusion in GW Law Faculty Publications \& Other Works by an authorized administrator of Scholarly Commons. For more information, please contact spagel@law.gwu.edu. 


\section{Judicial Innovations to Screen Eyewitness Identifications}

\section{BY STEPHEN A. SALTZBURG}

I $\mathrm{n}$ a decision announced November 29, 2012, the Oregon Supreme Court reconsidered, after 30 years, the role that trial judges must play in Oregon courts to screen eyewitness identification. The case, State v. Lawson, 291 P.3d 673 (Or. 2012), actually consolidated two separate criminal appeals in order to broadly consider eyewitness identifications. The first defendant, Samuel Adam Lawson, was convicted of five counts of aggravated murder, three counts of attempted aggravated murder, and two counts of first-degree robbery (State v. Lawson); the second defendant, Stanley Dale James Jr., was convicted of second-degree robbery, harassment, and third-degree theft (State v. James).

\section{The Facts of Lawson}

The facts of Lawson illustrate the problems eyewitnesses often have in making identifications. On August 21, 2003, Noris and Sherl Hilde drove with their trailer to a campsite where Noris had pitched a tent the prior weekend to claim the spot. They found Lawson in the tent and his yellow truck parked in their parking space. Lawson apologized, saying he thought the tent was abandoned; he then moved to a nearby vacant campsite.

Later that evening, as she stood at the window of the trailer, Sherl was shot in the chest with a large caliber hunting rifle. Noris, was then shot and killed while trying to call 911 . When the 911 dispatcher called back, Sherl told the dispatcher that she and her husband were shot and that she did not know who shot them, but "they" (the shooter or shooters) wanted the Hildes' truck. Emergency personnel found Sherl lying in the trailer in critical condition, and transported her via ambulance and helicopter to a hospital. An ambulance attendant said she

STEPHEN A. SALTZBURG is the Wallace and Beverley Woodbury University Professor at George Washington University School of Law in Washington, D.C. He is a past chair of the Criminal Justice Section and a regular columnist for Criminal Justice magazine. He is also author of the book, Trial Tactics, Third Edition (American Bar Association 2013), an updated and expanded compilation of his columns. was hysterical and continued to refer to the shooter as "they," but also said the shooter was the man at their campsite; she even claimed that the pilot of the helicopter was the shooter. At the hospital, she immediately went into surgery.

Two days later, the police attempted to interview Sherl while she was heavily medicated with her hands restrained to keep her from removing a breathing tube. Unable to speak, she could respond to questions only by moving her head. The police showed her a black-and-white photo line-up that included a picture of the defendant, who had volunteered to police that he encountered the couple the day they were shot. Sherl indicated she could not identify any photo, but she nodded "yes" to three leading questions: Had she seen the shooter earlier in the day? Had the shooter been in the Hildes' tent? Did the shooter drive a yellow truck?

Two weeks later, the police again interviewed Sherl at the hospital. This time, she could speak and told the police that the shooter entered the trailer after her husband was shot, but she could not see the man because it was dark and he put a pillow over her face. She was apologetic that she could not be more helpful to the police, but she did not think she could identify anyone. About two weeks after that, Sherl was again interviewed and told the police that, despite the pillow over her face, she briefly saw the shooter though she was still unable to pick him out of a photo line-up. She added that the perpetrator was wearing a dark shirt and a baseball cap, but did not indicate he was the same man who had been in their tent.

In an interview a week later, Sherl reviewed her answers to the leading questions she had been asked at the first interview. She had no recollection of the interview, but for the first time told the police that she believed the shooter was the man who had been in their tent earlier in the day. She stated she could not "swear to it" and did not think she could pick him out of a line-up. The police told her the man she identified was Samuel Lawson and he was in custody.

Later, while convalescing, a rehabilitation worker showed Sherl a newspaper with a photograph of Lawson that identified him as the suspect arrested for the shootings. Then, about a month before trial, and two years after the shootings, police investigators showed her a single photograph of Lawson wearing a dark shirt and a dark hat with white lettering and took her to a pretrial hearing where she observed him. Inadvertently, Sherl then came upon one of the previous photographic line-ups she had been shown. This time, she identified Lawson as the shooter, and went on to testify at his trial that Lawson was the shooter. The trial judge denied a motion to exclude the identification. 


\section{The Facts of James}

In James, Officer Gomez arrived at a local Safeway in response to a morning theft complaint. $\mathrm{He}$ discovered that the thieves were gone and interviewed employees who gave a description of two suspects that Gomez included in an incident report. One store clerk said he heard the "clanging" of bottles and then came upon a "large Indian" and a "small Indian" stuffing 40-ounce bottles of beer into a backpack. The clerk reported this to a manager, identified the two men as they were leaving, and the two Safeway employees pursued the men while yelling for them to stop. The smaller man left the store while the larger man blocked the exit. The store clerk tried to get around the larger man, and the larger man resisted and punched the manager as he swung at the clerk and missed. The two suspects ran across the parking lot and drove away.

The employees described the larger man as approximately 220 pounds, wearing a white tank top and baggy blue jeans, and the smaller man as approximately five feet tall, 110 pounds, and wearing a long black coat with a hood, baggy blue pants, and a backpack.

Later that day, Gomez observed two men who matched the descriptions. He approached the two, both of whom appeared intoxicated, and they denied having been at the Safeway. Gomez obtained consent to search one man's backpack and discovered one unopened 40-ounce bottle of Steel Reserve 211 malt liquor and a denim jacket. Gomez obtained consent to take both men to the Safeway, where they were identified by the clerk and manager. Gomez testified at a suppression hearing almost two years later that he said something like "Is this them?" before the Safeway employees made the identification.

The trial judge denied a motion to suppress the out-of-court and in-court identifications. The Oregon Court of Appeals affirmed.

\section{The Old Law}

The lower courts relied upon State v. Classen, 590 P.2d 1198 (Or. 1979), in making their rulings. That decision established a two-step process for evaluating identifications. First, the judge must decide whether the underlying identification process had either been suggestive or needlessly departed from procedures designed to avoid such suggestiveness. If so, the judge must then decide (1) whether the witness had based the identification at issue on an independent source separate from the suggestive elements, or (2) whether other aspects of the identification substantially excluded the risk that it had been influenced by the suggestive elements. In the second step, judges could consider, inter alia, five factors: (1) the opportunity that the witness had to clearly view the persons involved in the crime; (2) the attention that he or she gave to their identifying features; (3) the timing and completeness of the description given by the witness after the event; (4) the degree of certainty expressed by the witness in describing the persons involved in the crime and making subsequent identifications; and (5) the lapse of time between the original observation and the subsequent identification.

The Classen court relied on the US Supreme Court's 1977 decision in Manson v. Brathwaite, 432 U.S. 98, for these factors and for the proposition that reliability was the linchpin in determinations regarding the admissibility of identification testimony, but decided the case on the basis of Oregon evidence law rather than under the due process clause.

\section{Lawson and Evidence Law}

The Lawson court observed that the most recent United States Supreme Court case on identifications emphasized the role that state evidence law can play in excluding unreliable identifications. (Perry v. New Hampshire, 132 S. Ct. 716, 181 (2012).) It explained that much had changed since its 1979 Classen decision:

Since 1979 - the year that this court decided Classen - there have been more than 2,000 scientific studies conducted on the reliability of eyewitness identification. Amici curiae in these two cases - particularly the Innocence Network and a group of academics and university professors who have conducted, published, and reviewed a wide range of scientific research on the subject of eyewitness identificationsubmitted extensive data and analysis to this court regarding many of those studies. Based on our extensive review of the current scientific research and literature, we conclude that the scientific knowledge and empirical research concerning eyewitness perception and memory has progressed sufficiently to warrant taking judicial notice of the data contained in those various sources as legislative facts that we may consult for assistance in determining the effectiveness of our existing test for the admission of eyewitness identification evidence.

(Lawson, 291 P.3d at 685.)

The court explained that it found in the research that the factors affecting the reliability of identifications can be grouped in two categories: system variables and estimator variables.

System variables refer to the circumstances surrounding the identification procedure itself that are generally within the control of those administering the procedure. Estimator variables, by 
contrast, generally refer to characteristics of the witness, the alleged perpetrator, and the environmental conditions of the event that cannot (Id.)

be manipulated or adjusted by state actors.

The court identified the system variables as blind administration, pre-identification instructions, line-up construction, simultaneous versus sequential line-ups, show-ups, multiple viewings, suggestive questioning, co-witness and other contamination, suggestive feedback, and recording confidence. It identified the estimator variables as stress, witness attention, duration of exposure, environmental viewing conditions, witness characteristics and conditions, description, perpetrator characteristics, speed of identification, level of certainty, and memory decay.

Considering all of these variables, the court concluded that Classen failed to ensure that only sufficiently reliable identifications are admitted. It reasoned that the Classen first step conflated evidentiary principles with due process analysis and that under state evidence law "there is no reason to hinder the analysis of eyewitness reliability with purposeless distinctions between suggestiveness and other sources of unreliability." (Id. at 688-89.) The court explained that " $[\mathrm{w}]$ hen a criminal defendant has challenged the admissibility of eyewitness identification evidence by an appropriate pretrial motion, the manner in which Classen apportions the burden of proof in identification matters reflects more concern for due process principles than principles of evidence law." (Id. at 689.) This is because it is the defendant who must allege a constitutional violation. In contrast, it is the proponent of evidence such as identifications who normally bears the initial burden of establishing admissibility.

The court also recognized problems with the second step in Classen because trial courts applying the Classen factors rely heavily on the eyewitnesses' selfreports regarding suggestibility, whereas there was persuasive evidence to show that suggestive procedures can inflate the self-reported evidence regarding suggestiveness factors.

\section{Problems and Necessity}

The court recognized both the problems with eyewitness identification as well as its importance. As for the problems, the court wrote:

[I]n Classen, this court acknowledged that "extensive research and commentary by psychologists and jurists on the dangers of misidentification and ways to minimize them stretches back at least half a century" and "that the unreliability of eyewitness identification under suggestive circumstances is widely recognized." That said, a perfect solution to the problem of misidentification has thus far eluded us, a difficulty that may lie in the fact that, while empirical evidence suggests that a certain percentage of eyewitness identifications are incorrect, we often have no way to determine whether or not a particular eyewitness is accurate in identifying a specific individual. As we previously observed, although the scientific studies we have reviewed have identified a number of factors that contribute to the likelihood of mistaken identification, nearly all of those factors are probabilistic in naturethey can indicate only a statistical likelihood of misidentification within a broad population of people studied, not whether any one identification is right or wrong.

(Id. at 690 (footnote omitted) (citation omitted).)

As for the importance of such testimony, the court wrote that "[d]espite those shortcomings, eyewitness evidence can be extremely probative of guilt and, in many cases, may be the only evidence connecting a guilty defendant to a crime." (Id.) The court concluded that " $[t]$ herefore, we must attempt to strike a proper balance between the utility of that evidence in convicting the guilty and its proclivity, on occasion, to inculpate the innocent." (Id.)

\section{The Solution}

The court turned for a solution to the Oregon Evidence Code (OEC). It stated that, when a defendant makes a pretrial motion to suppress eyewitness identification, judges should recognize that such identification will almost always be relevant under OEC 401 (similar to Federal Rule of Evidence (FRE) 401), but that OEC 602 and 701 (similar to FRE 602 and 701) become important. OEC 602 requires that the proponent of eyewitness identification "must offer evidence showing both that the witness had an adequate opportunity to observe or otherwise personally perceive the facts to which the witness will testify, and did, in fact, observe or perceive them, thereby gaining personal knowledge of the facts." (Lawson, 291 P.3d at 692.)

OEC 701, the court ruled, requires the following: [T] he first part of an OEC 701 inquiry requires that the trial court initially consider what the witness actually perceived (essentially, the OEC 602 inquiry described above), and then determine whether the witness's identification of the defendant was "rationally based" on those perceptions. To satisfy its burden, the proponent of the identification evidence (generally the state) must demonstrate by a preponderance of the evidence that the witness perceived sufficient facts to support an 
inference of identification and that the identification was, in fact, based on those perceptions.

Initially, the proponent of the evidence must establish that the witness could make a rational inference of identification from the facts that the witness actually perceived. Human facial features will ordinarily be sufficiently distinctive to serve as a rational basis for an inference of identification. Thus, a witness who got a clear look at the perpetrator's face could rationally base a subsequent identification on a comparison of facial features, even if the witness was unable to verbally communicate every specific similarity between the two faces.

Conversely, nonfacial features like race, height, weight, clothing, or hair color, generally lack the level of distinction necessary to permit the witness to identify a specific person as the person whom the witness saw. If, for example, a witness testified to observing a tall, darkhaired man of medium build from behind as he ran from the scene of the crime, the trial court permissibly could find that the witness had personal knowledge of the height, build, clothing, and hair color of the perpetrator, but no more, and limit the testimony accordingly.

When a witness's perceptions are capable of supporting an inference of identification, but are nevertheless met with competing evidence of an impermissible basis for that inferencei.e., suggestive police procedures - an issue of fact arises as to whether the witness's subsequent identification was derived from a permissible or impermissible basis. When there are facts demonstrating that a witness could have relied on something other than his or her own perceptions to identify the defendant, the state - as the proponent of the identificationmust establish by a preponderance of the evidence that the identification was based on a permissible basis rather than an impermissible one, such as suggestive police procedures. (Lawson, 291 P.3d at 693.)

The court added that the eyewitness testimony must be helpful to the jury, which it usually will be, but:

it is conceivable that some statements of identification might not be particularly helpful to a jury. Consider, for example, the witness who observes a masked perpetrator with prominently scarred or tattooed hands. Although those features could be distinctive enough to provide a rational basis for an inference of identification, a jury may be equally capable of making the same inference by comparing the witness's description of those markings to objective evidence of the actual markings on the defendant.

(Id.)

The court added that a trial judge must consider whether the probative value of identification evidence is substantially outweighed by dangers of unfair prejudice, and "in cases in which an eyewitness has been exposed to suggestive police procedures, trial courts have a heightened role as an evidentiary gatekeeper because 'traditional' methods of testing reliability - like cross-examination - can be ineffective at discrediting unreliable or inaccurate eyewitness identification evidence." (Id. at 695.)

The court pointed out the potential importance of expert testimony:

Because many of the system and estimator variables that we described earlier are either unknown to the average juror or contrary to common assumptions, expert testimony is one method by which the parties can educate the trier of fact concerning variables that can affect the reliability of eyewitness identification. Expert testimony may also provide an avenue to introduce and explain scientific research or other indicia of reliability not specifically addressed by our opinion in these cases. In that regard, the use of experts may prove vital to ensuring that the law keeps pace with advances in scientific knowledge, thus enabling judges and jurors to evaluate eyewitness identification testimony according to relevant and meaningful criteria. Of course, expert testimony must be predicated on scientific research; must meet the threshold admissibility requirements for scientific evidence; and must be relevant to a disputed issue in the case, such that the testimony will assist the jury in resolving that issue. (Id. at 696 (citation omitted).)

Having set forth a new approach to eyewitness testimony, the court predicted:

that the trial courts will continue to admit most eyewitness identifications. . . . because, although possible, it is doubtful that issues concerning one or more of the estimator

Published in Criminal Justice, Volume 28, Number 2, Summer 2013. C 2013 by the American Bar Association. Reproduced with permission. All rights reserved. This information or any portion thereof may not be copied or disseminated in any form or by any means or stored in an electronic database or retrieval system without the express written consent of the American Bar Association. 
variables that we have identified will, without more, be enough to support an inference of unreliability sufficient to justify the exclusion of the eyewitness identification.

(Id. at 697.)

\section{Conclusion}

In Lawson, the court reversed and remanded for a new trial and stated that "the parties must be permitted on retrial to (1) supplement the record with any additional evidence that may bear on the reliability of the eyewitness identifications at issue here, and (2) present arguments regarding the appropriate application of the new procedures set out in this opinion." (Id. at 698-99.) In James, the court "conclude[d] that, unlike Lawson, application of the revised test that we have established here could not have resulted in the exclusion of the eyewitness identification evidence" and accordingly affirmed the conviction. (Id. at 699.)

Other state courts have expressed concern about the dangers of erroneous convictions based on eyewitness identifications. One example cited by the
Oregon Supreme Court is the opinion of the New Jersey Supreme Court in State v. Henderson, 27 A.3d 872 (N.J. 2011), together with the report of the special master engaged in that case.

Footnote 5 of Lawson highlights that court's concern: "Eyewitness misidentification has contributed to date to 72 percent of the 301 wrongful convictions revealed by DNA evidence." (Lawson, 291 P.3d at 690 n.5 (citing Facts on Post-Conviction DNA Exonerations, InNOCENCE PROJeCt, http:// tinyurl.com/25frwdr (last visited Apr. 14, 2013); Brandon L. Garrett, Convicting the InNocent: Where Criminal Prosecutions Go Wrong 48 (2011) (reporting that 76 percent of the first 250 convictions overturned due to DNA evidence since 1989 involved eyewitness misidentification)).)

Prosecutors, along with judges and defense lawyers, desire to prevent wrongful convictions, including those based on eyewitness identification. The hope is that all concerned will cooperate in state experiments that might lead to better investigative procedures and judicial controls that will reduce the danger of convicting the innocent. 